\title{
ISOLASI DAN UJI ANTIFUNGAL BAKTERI ENDOFIT DARI AKAR TANAMAN KARET (Hevea brasilliensis)
}

\section{ISOLATION AND ANTIFUNGAL TEST OF ENDOPHYTIC BACTERIA FROM ROOTS OF RUBBER PLANTS (Hevea brasilliensis)}

\author{
Widya Lestari \\ Program Studi Agroteknologi, Sekolah Tinggi Ilmu Pertanian Labuhan Batu \\ Aek Tapa Rantauprapat \\ Koresponden: widya.chubby@yahoo.co.id
}

\begin{abstract}
Abstrak
Penelitian mengenai bakteri endofit dalam mengendalikan hama dan penyakit tanaman serta meningkatkan pertumbuhan tanaman dengan menghasilkan metabolit sekunder telah banyak dilaporkan. Penelitian ini bertujuan untuk mengetahui kemampuan bakteri endofit dari akar tanaman karet dalam menghambat pertumbuhan fungi patogen. Isolasi bakteri endofit dilakukan dengan sterilisasi permukaan akar dan mengkulturnya pada media nutrien agar. Lima isolat bakteri endofit diperoleh dari akar tanaman karet masing-masing: WL01, WL02, WL03, WL04 dan WL05. Isolat bakteri diuji antagonis terhadap fungi patogen yaitu Fusarium oxysporum, Ganoderma boninense, Rigidoporus microporus dan Saprolegnia sp. Dua isolat bakteri, WL01 dan WL05 memiliki kemampuan dalam menghambat pertumbuhan fungi patogen Rigidoporus microporus dan Fusarium oxysporum. Hasil pengamatan menyatakan bahwa pertumbuhan fungi patogen terhambat dan hifa bengkok.
\end{abstract}

Kata Kunci: Bakteri endofit, Fusarium oxysporum, Rigidoporus microporus, Tanaman karet (Hevea brasilliensis)

\begin{abstract}
Researches on endophytic bacteria in controlling plant pests and diseases and increasing plant growth by producing secondary metabolites has been widely reported. This study aims to determine the ability of endophytic bacteria from the roots of rubber plants in inhibiting the growth of pathogenic fungi. Endophytic bacterial isolation was performed by root surface sterilization and cultured on nutrient agar medium. Five endophytic bacterial isolates were obtained from the root of each rubber plant: WL01, WLO2, WLO3, WLO4 and WL05. Bacterial isolates were tested antagonistically against pathogenic fungi, namely Fusarium oxysporum, Ganoderma boninense, Rigidoporus microporus and Saprolegnia sp. Two bacterial isolates, WLO1 and WLO5 had the ability to inhibit the growth of pathogenic fungi Rigidoporus microporus and Fusarium oxysporum. The observations showed that the growth of pathogenic fungi was inhibited and hyphae were bent.
\end{abstract}

Keywords: Endophytic Bacteria, Fusarium Oxysporum, Rigidoporus Microporus, Rubber Plants (Hevea Brasilliensis) 


\section{PENDAHULUAN}

Salah satu masalah utama dari budidaya tanaman pertanian di Indonesia ialah adanya serangan fungi patogen terhadap berbagai tanaman antara lain tanaman cabai, kacang kacangan, coklat, karet dan kelapa sawit. Serangan fungi patogen tersebut mengakibatkan kerugian yang sangat besar bagi para petani. Untuk itu diperlukannya suatu penanggulangan yang efektif. Selama ini telah banyak dilakukan pengendalian fungi patogen pada tanaman secara kimiawi, akan tetapi menimbulkan efek negatif terhadap lingkungan. Untuk itu perlu diupayakan suatu alternatif pengendalian secara biologi dengan menggunakan mikroba antagonis atau menggunakan metabolit antimikroba yang dihasilkan.

Menurut Cook dan Baker (1999), usaha penanggulangan penyakit tanaman secara biologis mempunyai peluang yang cukup besar karena organismenya telah tersedia di alam dan aktivitasnya dapat distimulasi dengan memodifikasi lingkungan maupun tanaman inang. Keuntungan dalam menggunakan mikroorganisme antagonis sebagai pengendalian biologis antara lain: aman terhadap lingkungan, tidak ada efek residu, aplikasinya bersifat berkelanjutan karena yang digunakan organisme hidup yang dapat memperbanyak diri sehingga dapat mengurangi aplikasi yang berulang-ulang.

Penelitian bakteri endofit telah dilakukan lebih dari 20 tahun yang lalu. Hampir setiap bagian tanaman ditemukan adanya jamur endofit, baik pada daun, akar maupun batang. Dalam beberapa tahun terakhir, pengaplikasian mikroba endofit sebagai pengendali biologis telah menjadi alternatif untuk menggantikan peran pengendali kimia seperti pestisida. Penggunaan agen biologis ini secara alami mampu mengendalikan populasi hama, meningkatkan produksi tanaman dan merupakan pilihan yang baik bagi resistensi penyakit dan juga ramah lingkungan (Procopio et al., 2009).

Tanaman tingkat tinggi mengandung beberapa mikroba endofit yang menghasilkan metabolit sekunder sebagai bentuk pertahanan terhadap mikroba patogen (Radji, 2005). Tanaman karet memiliki bakteri endofit, karet merupakan pohon yang tumbuh tinggi dan memiliki batang yang cukup besar. Tinggi pohon dewasa dapat mencapai 15-25 m dengan diameter . Batang karet tumbuh lurus ke atas dan cenderung miring ke arah utara. Bagian batang inilah yang mengandung getah atau lateks. Lingga (2013) telah mengisolasi jamur endofit dari tumbuhan mentigi. Penelitian ini diperlukan untuk mengetahui manfaat bakteri endofit yang ada pada akar tanaman karet sebagai agen pengendalian hayati. 


\section{METODOLOGI PENELITIAN}

\section{Isolasi Bakteri Endofit Dari Akar Tanaman Karet}

Isolasi bakteri endofit dari akar dan daun dilakukan dengan metode sterilisasi permukaan menurut metode Radu \& Kqueen (2002). Sampel yang diambil dari lokasi dimasukkan ke dalam plastik diletakkan di dalam termos yang berisi es batu, kemudian sampel dibawa ke laboratorium mikrobiologi untuk isolasi bakteri endofit. Tahap awal yang dilakukan adalah mencuci akar dengan air mengalir selama 20 menit. Sterilisasi bagian permukaan akar dilakukan dengan cara merendamnya di dalam larutan secara berturut-turut: etanol 75\% selama 2 menit, larutan sodium hipoklorit 5,3\% selama 5 menit dan etanol 75\% selam 30 detik. Selanjutnya akar dibilas dengan akuades steril, setelah kering bagian ujung kiri dan kanan akar dipotong $1 \mathrm{~cm}$, kemudian masing-masing akar dipotong membujur dan diletakkan di permukaan media NA yang telah dicampur dengan antibiotik ketokonazole $(0,3$ $\mathrm{g} / 100 \mathrm{ml}$ ) dengan posisi bekas potongan ke arah media, kemudian diinkubasi pada suhu ruang selama 5 hari. Koloni yang muncul disubkultur ke media NA yang baru untuk dimurnikan.

\section{Karakterisasi Bakteri Endofit Akar Tanaman Karet}

Isolat bakteri yang diperoleh dari akar dikarakterisasi secara morfologi meliputi bentuk, warna, elevasi, tepi koloni dan uji biokimia mencakup uji sitrat, uji katabolisme gula, uji motilitas, uji gelatin, uji katalase.

\section{Uji Antifungal Bakteri Endofit Akar Tanaman Karet}

Uji antagonis dilakukan untuk melihat kemampuan bakteri endofit dalam menghambat pertumbuhan fungi patogen seperti $F$. oxysporum, G. boninense, Saprolegnia sp. dan $R$. microporus. Biakan kultur jamur patogen yang sudah diremajakan diambil dengan cork borer, lalu diinokulasikan pada bagian tengah media modifikasi PDA + YE 1\% dengan jarak 3,5 cm dari cakram tempat inokulum isolat bakteri lalu biakan tersebut diinkubasi selama 72 jam pada suhu ruang. Pengujian daya hambat isolat bakteri endofit terhadap jamur patogen, menggunakan metode difusi cakram kertas sesuai dengan metode Kirby-Baur (Mishra et al., 2006; Kulsuntiwong et al., 2008). Sebanyak $10 \mu \mathrm{l}$ suspensi isolat bakteri endofit dengan kerapatan $\approx 10^{8} \mathrm{CFU} / \mathrm{ml}$, diteteskan pada kertas cakram (Oxoid) yang 
berdiameter 0,6 cm. Selanjutnya uji antagonis dilakukan dengan cara meletakkan cakram tersebut pada 2 titik di tepi media PDA + YE $1 \%$, kemudian diinkubasi pada suhu ruang selama 7 hari. Isolat bakteri endofit yang berpotensi antagonis ditunjukkan dengan adanya zona hambatan terhadap pertumbuhan miselium beberapa fungi patogen. Masing-masing perlakuan dilakukan dengan 2 kali pengulangan. Pengamatan dilakukan terhadap pengukuran zona hambat yang terbentuk di sekitar cakram kertas yang menunjukkan adanya aktivitas antimikroba (Lechevalier, 2000). Pengujian dilakukan terhadap semua jamur patogen.

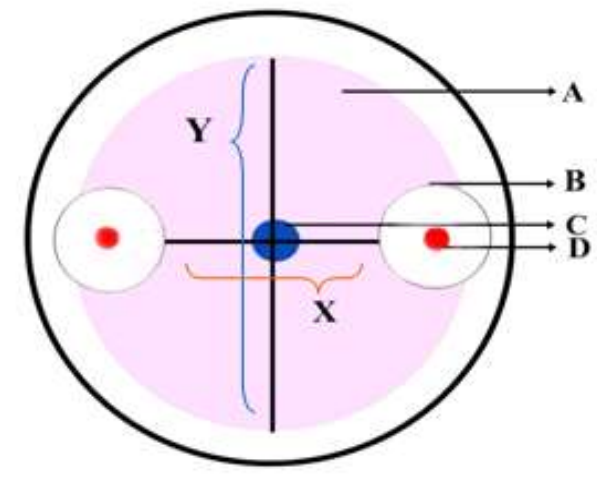

Gambar 1. Metode pengukuran zona hambat bakteri endofit terhadap koloni fungi; A. Koloni fungi, B. Zona hambat bakteri endofit terhadap koloni fungi, C. Titik tengah jamur diletakkan, D. Koloni bakteri endofit , X. Diameter koloni fungi yang terhambat pertumbuhannya, Y. Diameter koloni fungi normal (Suryanto, 2006).

Pengukuran diameter zona hambat bakteri dilakukan dengan menggunakan jangka sorong. Zona hambat isolat bakteri endofit dihitung dengan rumus uji antagonis $(\mathrm{Y}-\mathrm{X}) / 2=$ hasil (Suryanto et al., 2006). Masing-masing ekstrak metanol, n-heksana dan etil asetat dilarutkan dengan dimetil sulfoksida (DMSO) dengan konsentrasi masing-masing 40, 60, 80 dan $100 \%$. Pengujian daya hambat isolat terhadap jamur patogen menggunakan metode difusi cakram kertas sesuai dengan metode Kirby-Bauer (Drew et al., 1971; Mishra et al., 2006; Kulsuntiwong et al., 2008). Uji antagonis dilakukan dengan cara meletakkan cakram yang berisi dengan metabolit sekunder bakteri endofit tersebut, di tepi media PDA + YE $1 \%$ kemudian diinkubasi pada suhu ruang selama 7 hari. Aktivitas antifungal ditunjukkan dengan adanya zona hambatan pertunbuhan organisme uji di sekitar koloni penghasil antibiotik (Lechevalier, 2000). Pengujian dilakukan terhadap semua jamur patogen. Masing-masing perlakuan dilakukan dengan 2 kali pengulangan. 


\section{Pengamatan Miselium Jamur Patogen Setelah Uji Antagonis}

Pengamatan dilakukan dengan 2 cara yaitu secara visual dan mikroskopis. Pengamatan secara visual dilakukan dengan cara melihat zona pertumbuhan. Pengamatan secara mikroskopis dilakukan dengan cara mengamati ujung miselium pada zona hambat beberapa jamur patogen. Ujung miselium fungi patogen yang tumbuh pada permukaan media PDA dipotong berbentuk block square, kemudian diletakkan pada objek gelas. Selanjutnya diamati adanya abnormalitas pertumbuhan miselium fungi patogen berupa pembengkokan ujung miselium dan miselium pecah, miselium berbelah, miselium bercabang, miselium lisis dan miselium tumbuh kerdil (Lorito et al., 1992).

\section{HASIL DAN PEMBAHASAN}

\section{Isolasi dan Karakterisasi Bakteri Endofit dari Akar Tanaman Karet}

Dari hasil isolasi yang telah dilakukan dari bagian akar tanaman karet (Hevea brasiliensis), diperoleh 5 (lima) isolat bakteri yang diberi kode: WL01, WL02, WL03, WL04 dan WL05 yang merupakan total bakteri endofit yang didapat dari tanaman karet perkebunan swasta dan perkebunan rakyat. Karakterisasi yang dilakukan pada isolat bakteri meliputi bentuk morfologi sel, bentuk koloni dan penataannya serta beberapa uji biokimia sederhana. Hasil pengamatan morfologi dan uji biokimia sederhana terhadap isolat dapat dilihat pada tabel di bawah ini:

Tabel 1. Karakterisasi Morfologi Koloni dan Sel Isolat Bakteri Endofit

\begin{tabular}{|c|c|c|c|c|c|c|c|}
\hline \multirow{2}{*}{ Isolat } & \multicolumn{4}{|c|}{ Morfologi Koloni } & \multicolumn{2}{|c|}{ Morfologi Sel } & \multirow{2}{*}{ Gram } \\
\hline & Warna & Bentuk & Tepi & Elevasi & Bentuk & Penataan & \\
\hline WL01 & Merah & Tidak beraturan & Rata & Datar & Kokus & Mono & - \\
\hline WL02 & Kuning & Bulat & Rata & Datar & Batang & Mono & + \\
\hline WL03 & $\begin{array}{c}\text { Transpar } \\
\text { an }\end{array}$ & Bulat & Rata & Datar & Kokus & Mono & + \\
\hline WL04 & Merah & Tidak Beraturan & Berbelah & Cembung & Kokus & Mono & - \\
\hline WL05 & Merah & Bulat & Rata & Datar & Kokus & Mono & - \\
\hline
\end{tabular}
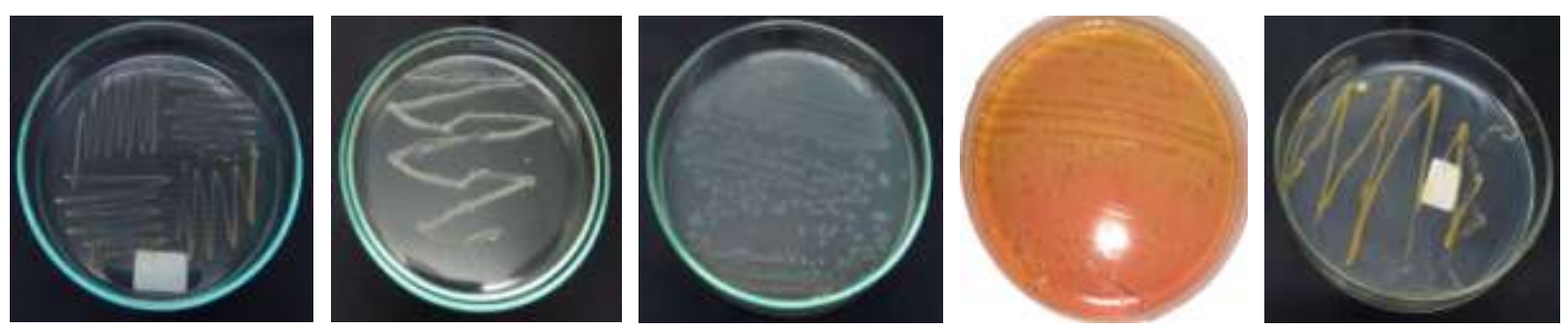

Gambar 2. Isolat Bakteri Endofit Hasil Isolasi Dari Akar Tanaman Karet 


\section{Kemampuan Antagonis Bakteri Endofit terhadap Fungi patogen Tanaman}

Isolat bakteri yang berpotensi menghambat jamur pada tahapan isolasi, selanjutnya digunakan pada asai antagonis, untuk melihat kemampuannya dalam menghambat pertumbuhan jamur. Jamur patogen yang digunakan yaitu: $F$. oxysporum, $G$. boninense, $R$. microporus dan Saprolegnia sp. Dasar pemilihan sampel yaitu mewakili beberapa jamur patogen penyebab penyakit pada tanaman.

\section{Uji Antifungal Bakteri Endofit Akar Tanaman Karet}

Berdasarkan hasil uji antagonis kelima isolat menunjukkan potensi 2 (dua) isolat terhadap Fusarium oxysporum dan Rigidoporus microsporus yang mana kedua isolat tersebut akan digunakan untuk produksi senyawa antifungal melalui prosedur ekstraksi. Keseluruhan hasil uji tantang dapat dilihat pada Tabel di bawah ini:

Tabel 2. Zona Hambat Uji Antagonis Isolat Bakteri Endofit dengan Jamur Patogen

\begin{tabular}{ccccccc}
\hline \multirow{2}{*}{ Kode } & \multicolumn{5}{c}{ Rerata Zona Hambat (mm) } \\
\cline { 2 - 7 } Isolat & \multicolumn{5}{c}{ Fusarium oxysporum } & \multicolumn{2}{c}{ Rigidoporus microsporus } \\
\cline { 2 - 7 } & Hari ke-5 & Hari ke-6 & Hari-7 & Hari ke-5 & Hari ke-6 & Hari ke-7 \\
\hline WL01 & 14,80 & 15,60 & 15,80 & 16,80 & 17,40 & 18,00 \\
WL02 & 0 & 0 & 0 & 0 & 0 & 0 \\
WL03 & 0 & 0 & 0 & 0 & 0 & 0 \\
WL04 & 0 & 0 & 0 & 0 & 0 & 0 \\
WL05 & 16,60 & 18,00 & 22,20 & 10,00 & 15,60 & 18,10 \\
\hline
\end{tabular}
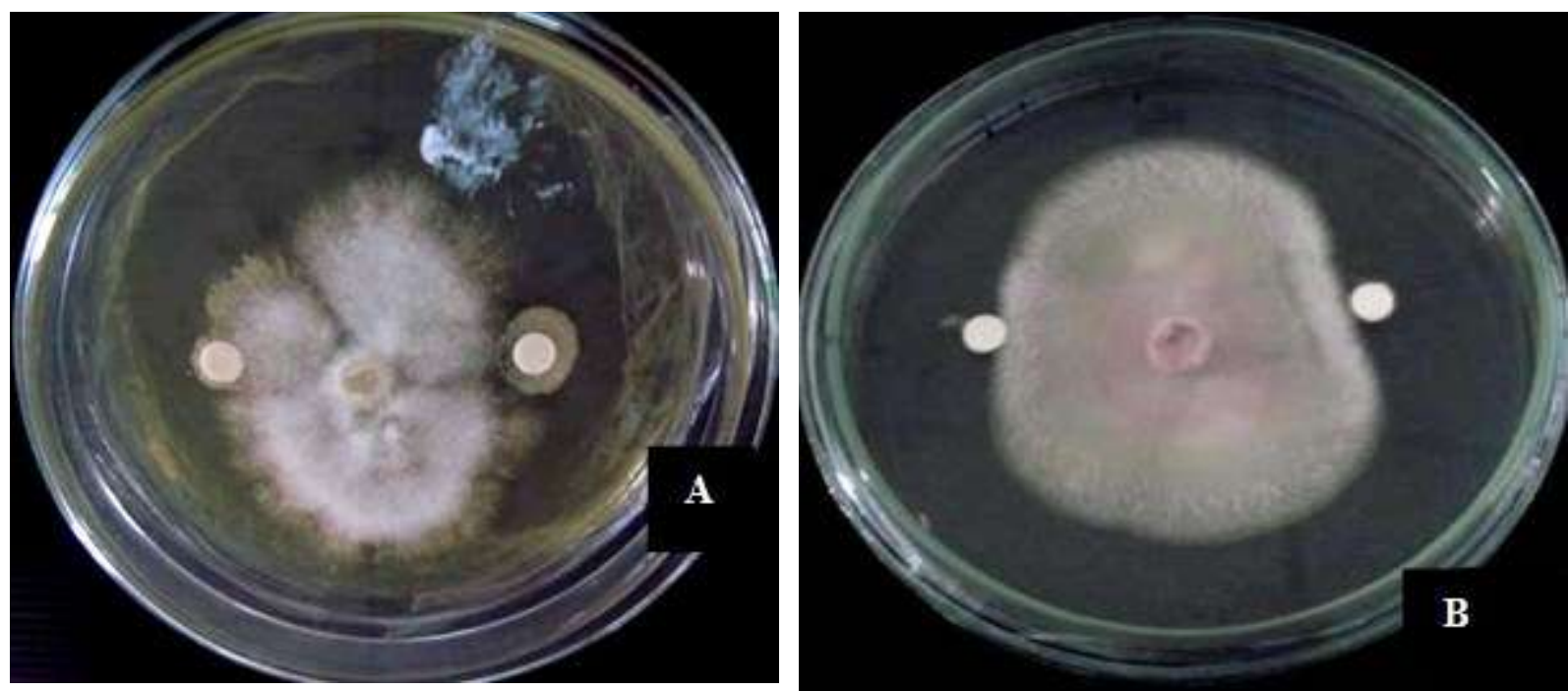

Gambar 3. Uji Antagonis WL01 terhadap A. F. oxysporum dan B. R. microsporus 


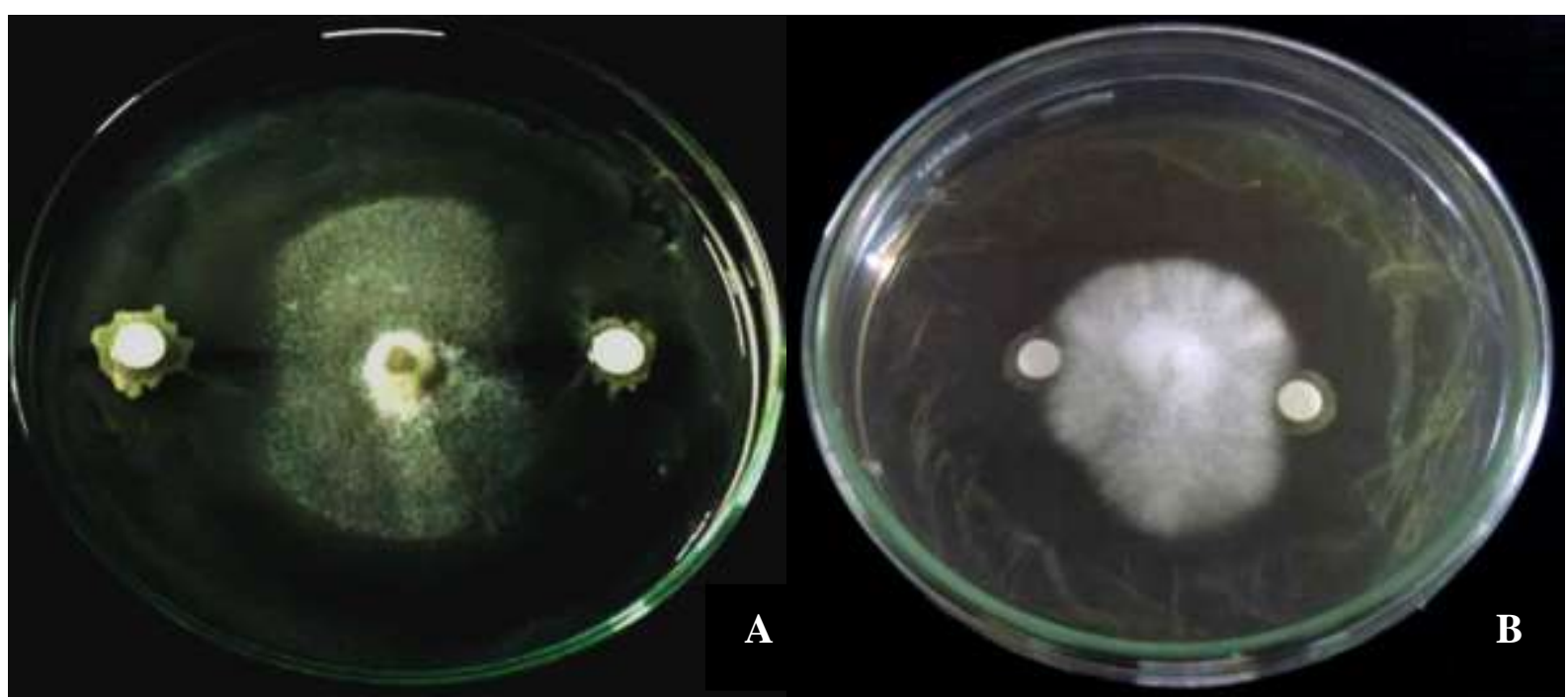

Gambar 4. Uji Antagonis WL05 terhadap A. F. oxysporum dan B. R. microspores

Dari gambar di atas dapat dilihat bahwa zona hambat dari hasil uji antagonis antara bakteri endofit dengan jamur patogen berbeda beda. Hal ini mungkin disebabkan karena bakteri endofit menghasilkan senyawa metabolit sekunder berbeda, selain itu konsentrasi zat bioaktif dan jenis zat yang dihasilkan oleh bakteri berbeda beda pula dalam menghambat pertumbuhan jamur patogen.

Mikroba khususnya bakteri memiliki kemampuan menghambat pertumbuhan mikroba lain disebabkan karena bakteri dapat menghasilkan senyawa metabolit sekunder seperti senyawa antimikroba, antibiotik (Wright et al., 2001), enzim pelisis (Zhang \& Yuen 2000; Kim et al., 2008), antivirus, antiparasit dan protein penghambat lain (Berdy 2005; Borodina et al., 2005; Lestari 2001; Price et al., 1999). Pembentukan senyawa metabolit sekunder ini dikode oleh sejumlah gen yang terdapat pada DNA kromosom atau DNA plasmid (Demain, 1998).

Isolat bakteri yang diujikan menunjukkan kemampuan menghambat jamur patogen $R$. microporus dan $F$. oxysporum. Hal ini mungkin disebabkan karena pengaruh media yang digunakan dan perbedaan dinding sel penyusun dari jamur yang digunakan dalam uji antagonis. Ketika nutrisi mulai berkurang bakteri akan memasuki fase stasioner dan pada fase ini diduga terjadi pembentukan senyawa metabolit sekunder yang bersifat antifungi.

Bakteri yang memiliki kemampuan dalam menghambat pertumbuhan jamur Rigidoporus microporus dan Fusarium oxysforum adalah bakteri W5 dan AW6 yang dapat menghambat semua jamur patogen uji, sedangkan isolat WL02, WL03, WL04 tidak mampu 
menghambat pertumbuhan jamur F. oxysporum dan R. microporus. Menurut Bakri (2009), Isolat bakteri tersebut memiliki kemampuan antagonistik yang ditandai dengan adanya penghambatan miselium jamur patogen tanaman dan pada akhirnya pertumbuhan hifa menipis, mengering dan mengalami abnormalitas.

Tabel 3. Deskripsi Gejala Antagonis Yang Terjadi Antara Isolat Fungi

\begin{tabular}{|c|c|c|}
\hline Kode Isolat & Fungi patogen yang dihambat & Gejala Antagonis \\
\hline WL01 & R. microporus & $\begin{array}{l}\text { Pertumbuhan fungi patogen terhambat, hifa } \\
\text { bengkok }\end{array}$ \\
\hline WL02 & $\begin{array}{l}\text { F. oxysporum } \\
R . \text { microporus }\end{array}$ & Pertumbuhan fungi patogen tidak terhambat \\
\hline WL03 & R. microporus & Pertumbuhan fungi patogen tidak terhambat \\
\hline WL04 & $\begin{array}{l}\text { F. oxysporum } \\
R \text {. microporus }\end{array}$ & Pertumbuhan fungi patogen tidak terhambat \\
\hline WL05 & $\begin{array}{l}F . \text { oxysporum } \\
R . \text { microporus }\end{array}$ & $\begin{array}{l}\text { Pertumbuhan fungi patogen terhambat, hifa } \\
\text { bengkok, menggulung dan lisis. }\end{array}$ \\
\hline
\end{tabular}

Mekanisme penghambatan agen hayati dalam menekan pertumbuhan patogen adalah melalui mekanisme mikoparasitisme. Proses mikoparasitik terdiri atas empat tahap yaitu pertumbuhan kemotropis, pengenalan (rekognisi), pelekatan dan pelilitan, dan lisis (Soesanto et al., 2008).

\section{KESIMPULAN}

Dari penelitian yang telah dilakukan dapat disimpulkan bahwa diperoleh 5 isolat bakteri endofit dari akar tanaman karet (Hevea brasilliensis). Isolat WL01 dan WL05 memiliki kemampuan dalam menghambat pertumbuhan jamur Rigidoporus microporus dan Fusarium oxysporum.

\section{REFERENSI}

Bakri, M. 2009. Isolasi dan uji kemampuan antifungal fungi endofit dari tanaman Andaliman (Zanthoxylum acanthopodium DC.) terhadap fungi perusak makanan. Skripsi. USU. Medan.

Cook, R.J. and Baker, K.F. 1983. The Nature of Practice of Biological Control of Plant Pathogens. The APS Press, St. Paul, Minnesota. 53 p.

Demain AL. 1998. Induction of Microbial Secondary Metabolism. Review Article. Int Microbiol 1: 259-264. 
Kim YC, Jung H, KIM KY, Park SK. 2008. An effective biocontrol bioformulation against Phytophthora blight of pepper using growth mixtures of combined chitinolytic bacteria under different field conditions. Eur J Plant Pathol 120:373-382.

Lingga, R. 2013. Keragaman Jamur Endofit Pada Mentigi (Vaccinium varingaefolium) Di Kawah Gunung Sinabung Sumatera Utara. Tesis Megister Biologi Departemen Biologi FMIPA USU. Medan.

Lorito, M., Harman, G. E., Hayes, C. K., Broadway, R. M., Tronsmo, A., Woo, S. L. and de Pietro, A. 1992. Chitinolytic enzymes produced by Trichoderma harzianum antifungal activity of purified endochitinase and chitobiosidase. Phytopath. 83: 302307.

Procopio, R.E.L., Araujo, W., Maccheroni Jr, and Azevedo, J.L. 2009. Characterization of an endophytic bacterial community associated with Eucalyptus spp. Genet Mol Res 8 (4): 1408-1422.

Radji, M. 2005. Peranan bioteknologi dan mikroba endofit dalam pengembangan obat herbal. Majalah Ilmu Kefarmasian. 2 (3): 118-121.

Radu, S. and Kqueen, C.Y. 2002. Preliminary screening of endophytic fungi from medicinal plants in malaysia for antimicrobial and antitumor activity. Malaysian Journal of Medical Science, 9 (2): 23-33.

Soesanto, L, Rokhlani, dan Nur Prihatiningsih. 2008. Beberapa mikroorganisme antagonis terhadap penyakit layu fusarium gladiol. Agrivita. 30(1):76-83.

Suryanto, D., Siti K.N. and Erman M. 2012. Antimicrobial Activity of Some Bacterial Isolates natural Recreational Park of North Sumatera, Indonesia. Bulletin of Environment, Pharmacology and Life Sciences. 1(11). 1-7.

Suryanto, D. and Munir, E. 2006. Potensi isolat bakteri kitinolitik lokal untuk pengendalian hayati jamur. Prosiding seminar hasil-hasil penelitian USU 2006. Medan : 15-25.

Zhang Z, Yuen GY. 2000. Effects of culture fluids and preinduction of chitinase production on biocontrol of bipolaris leaf spot by Stenotrophomonas maltophilia C3. Biol Contr 18: $277-286$. 